in vivo $35: 13-22(2021)$

doi:10.21873/invivo.12227

Review

\title{
Therapeutic Application of Mesenchymal Stem Cells for Cochlear Regeneration
}

\author{
NAGARAJAN MAHARAJAN ${ }^{1 *}$, GWANG WON $\mathrm{CHO}^{1 *}$ and CHUL HO JANG ${ }^{2}$ \\ ${ }^{1}$ Department of Biology, College of Natural Science, BK21-Plus Research Team for \\ Bioactive Control Technology, Chosun University, Gwangju, Republic of Korea; \\ ${ }^{2}$ Department of Otolaryngology, Chonnam National University Medical School, Gwangju, Republic of Korea
}

\begin{abstract}
Hearing loss is one of the major worldwide health problems that seriously affects human social and cognitive development. In the auditory system, three components outer ear, middle ear and inner ear are essential for the hearing mechanism. In the inner ear, sensory hair cells and ganglion neuronal cells are the essential supporters for hearing mechanism. Damage to these cells can be caused by long-term exposure of excessive noise, ototoxic drugs (aminoglycosides), ear tumors, infections, heredity and aging. Since mammalian cochlear hair cells do not regenerate naturally, some therapeutic interventions may be required to replace the damaged or lost cells. Cochlear implants and hearing aids are the temporary solutions for people suffering from severe hearing loss. The current discoveries in gene therapy may provide a deeper understanding in essential genes for the inner ear regeneration. Stem cell migration, survival and differentiation to supporting cells, cochlear hair cells and spiral ganglion neurons are the important foundation in understanding stem cell therapy. Moreover, mesenchymal stem cells (MSCs) from different sources (bone marrow, umbilical cord, adipose tissue and placenta) could be used in inner ear therapy. Transplanted MSCs in the inner ear can recruit homing factors at the damaged sites to induce transdifferentiation into inner hair cells and ganglion
\end{abstract}

This article is freely accessible online.

*These Authors contributed equally to this study.

Correspondence to: Chul Ho Jang, MD, Ph.D., Department of Otolaryngology, Chonnam National University Hospital, Dongku, Hakdong 8, Gwangju, Republic of Korea. Tel: +82 622206774, e-mail: chulsavio@hanmail.net

Key Words: Cochlea, hearing, regeneration, mesenchymal stem cells, review. neurons or regeneration of sensory hair cells, thus enhancing the cochlear function. This review summarizes the potential application of mesenchymal stem cells in hearing restoration and combining stem cell and molecular therapeutic strategies can also be used in the recovery of cochlear function.

Ear is the sensitive organ that senses soundwaves from the external environment and transmits them to the inner ear through external auditory meatus. It is composed of three compartments outer, middle and inner ear. Each compartment has its specific role in the hearing process. The major hearing problems arise due to damage or injury in the middle ear and inner ear. Conductive hearing loss (CHL) and sensorineural hearing loss (SNHL) are the main categories of hearing loss. Conductive hearing loss is the problem of conducting sound waves in the middle ear (eardrum and auditory ossicles), which primarily caused by the earwax or fluid accumulation in the ear canal, perforated eardrum, benign tumors, severe middle and external ear trauma and chronic otitis media (1). Sensorineural hearing loss occurs when there is damage in the inner ear hair cells or insufficient function of hair cells and auditory neurons or impaired function of auditory neural pathways (2). Frequent exposure to loud noises, intake of ototoxic medications, viral infections, tumors, presbycusis (age-related hearing loss), heredity and malformation of the inner ear are the major causes of SNHL. No major treatments are available for SNHL. However, some external devices, including hearing aids and cochlear implants are available for improving auditory dysfunctions. Currently, novel approaches such as stem cell therapy, gene therapy, delivering small interfering RNA (siRNA) and microRNA (miRNA) molecules to the inner ear have been emerged to restore the abnormal hearing function (Figure 1). In inner ear regenerative medicine, mesenchymal stem cells (MSCs) are being a better therapeutic option due to their significant properties 


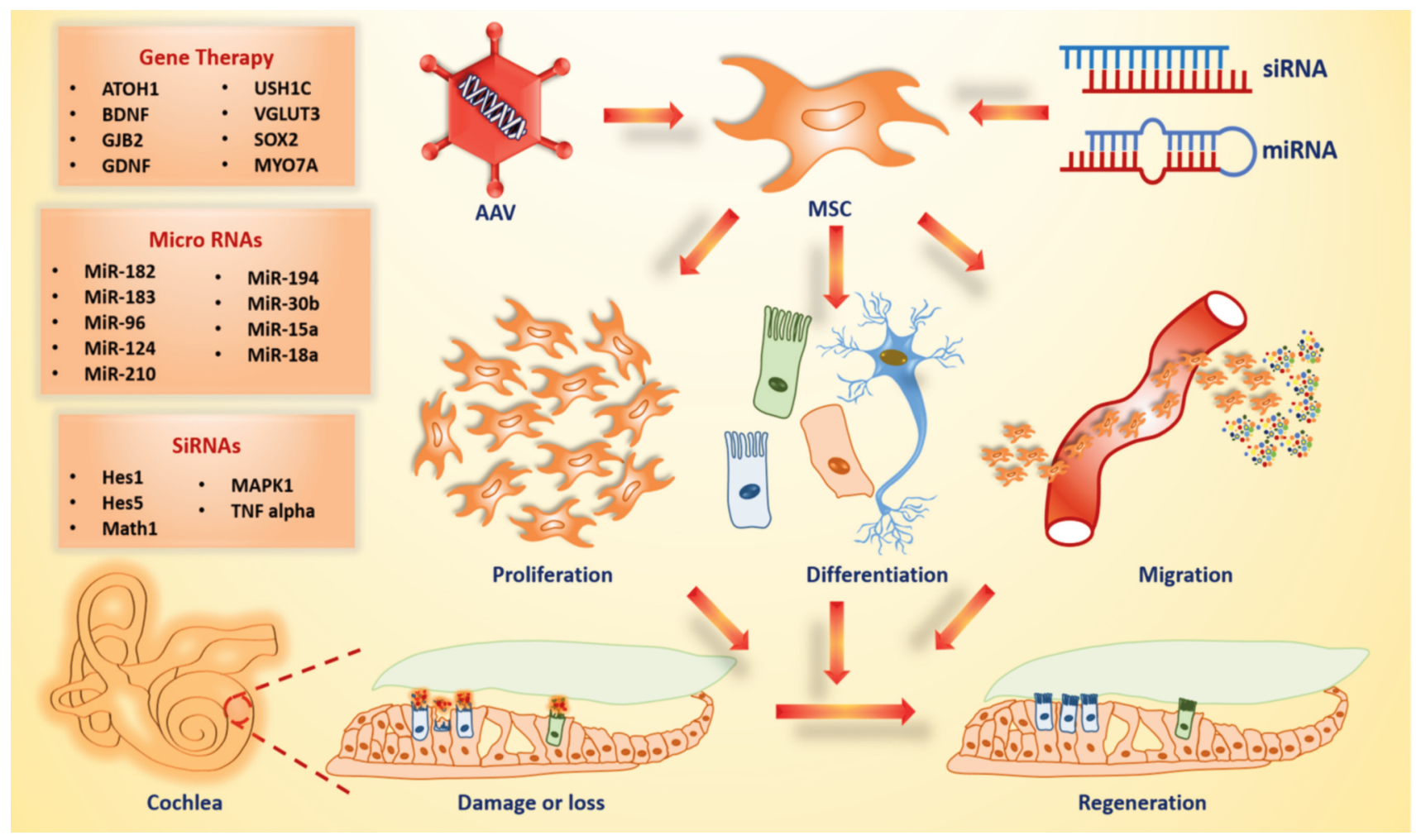

Figure 1. Application of gene manipulation techniques in mesenchymal stem cell enhances the possibility of regeneration of damaged or lost hair cells in the cochlea by inducing proliferation, differentiation, migration or secretion of paracrine factors. The list of important genes, microRNAs and siRNAs are used to study the hair cell regeneration (left).

including self-renewal, multipotency, paracrine action, immunomodulatory function and wound healing (3). Therefore, this review mainly focuses on the application of mesenchymal stem cells in inner ear hearing regeneration. Even though the mesenchymal stem cell approach shows beneficial outcome in hearing regeneration, a combination strategy of MSCs with different molecular approaches also currently evolved in hearing loss studies. Thus, we also highlighted MSCs in gene therapy, siRNA and miRNA for inner ear regeneration.

Inner Ear Regeneration. Cochlea is an important portion of inner ear structures, consists of specific numbers of small specialized cells called hair cells (HCs) and spiral ganglion neurons (SGNs), which are essential for transducing sound stimuli into electrical signals. Many cells in the body are able to regenerate themselves when injury occurs. But mammalian cochlear hair cells lack regenerative capacity, once they are impaired, their growth is irreversible and may end up with permanent hearing loss (4). Cochlea is mainly comprised of three chambers, scala vestibuli (vestibular duct), scala media (cochlear duct) and scala tympani (tympanic duct). The Reissner's membrane and basilar membranes separate the scala media from scala tympani and scala vestibuli. Perilymph and endolymph are the important fluids circulating in the inner ear. Perilymph is an extracellular fluid that circulates within the tympanic duct and vestibular duct and endolymph fluid filled the cochlear duct of the inner ear. The key components of these fluids are sodium and potassium ions, which are necessary for the appropriate sound stimuli transduction in the cochlea (5). Moreover, the lateral wall of the cochlea lining exists with spiral ligament and stria vascularis. The spiral ligament is made up of extracellular connective tissue materials and provides mechanical support for stria vascularis (6). Stria vascularis mainly regulates the endocochlear potential in the scala media and is functionally integrated with spiral ligament to mediate ion homeostasis in the cochlea. A core element of the scala media is the organ of Corti, which contains a series of inner hair cells, three series of outer hair cells and different types of non-sensory supporting cells. Different types of supporting cells (Deiter's cells, Pillar cells, Hensen's cells, Claudius cells, and Boettcher cells) present at the base of each hair cell with different morphological features and this presence offers structural and physiological support to the hair cells $(6,7)$. However, these supporting 
Table I. In vitro studies of mesenchymal stem cells (MSCs) in hearing regeneration.

\begin{tabular}{|c|c|c|c|c|}
\hline Author & $\begin{array}{l}\text { Type of mesenchymal } \\
\text { stem cells (MSCs) }\end{array}$ & $\begin{array}{l}\text { Addition of } \\
\text { supplements }\end{array}$ & $\begin{array}{l}\text { Differentiation } \\
\text { of cells }\end{array}$ & Reference \\
\hline J. Jeon et al. (2007) & Mice BM-MSCs & EGF, bFGF, IGF-1 & Inner ear hair cells & $(20)$ \\
\hline H. Qin et al. (2011) & Rat BM-MSCs & EGF, bFGF, IGF-1, B27, N2 & Inner ear hair cells & (68) \\
\hline Alonso et al. (2012) & Human BM-MSCs & EGF, bFGF, RA & Inner ear hair cells; auditory neurons & (69) \\
\hline Lee et al. (2012) & Rat BM-MSCs & GDNF, BDNF, NT-3 & Inner ear hair cells; auditory neurons & (36) \\
\hline Boddy et al. (2012) & Human BM-MSCs & IGF, EGF, bFGF, B27, N2 & Inner ear hair cells; auditory neurons & (70) \\
\hline Kil et al. (2016) & Human WJ-MSCs & EGF, bFGF, BDNF, GDNF, NT-3 & Inner ear hair cells and auditory neurons & (39) \\
\hline Mohammad et al. (2017) & Human BM-MSCs & EGF, bFGF, RA & Inner ear hair cells & (23) \\
\hline
\end{tabular}

EGF, Epidermal growth factor; bFGF, basic fibroblast growth factor; RA, retinoic acid; GDNF, glial cell-derived neurotrophic factor; BDNF, brainderived neurotrophic factor; NT3, neurotrophin-3; IGF, insulin-like growth factor.

cells are not contributing in sound transduction, playing an important role in hair cell regeneration through mitotic division or direct transdifferentiation (8). In the cochlea, numerous in vitro studies are being targeted auditory hair cells, ganglion neuronal cells, supporting cells and spiral ligament fibrocytes by different therapeutic approaches including stem cell therapy, gene therapy, siRNA nanoparticles, and miRNA.

Stem Cells. Different types of stem cells (embryonic stem cells, adult stem cells and induced pluripotent stem cells) have been involved in sensory hair cells and auditory neurons regeneration. Embryonic stem cells are pluripotent cells, derived from early embryos, that can differentiate into any embryonic cell type. ESCs were used in numerous studies to regenerate sensory hair-like cells and neuronal cells (9-11). Many countries have raised ethical concerns with the use of ESCs (12). Recently, a novel method has been developed for the first-time differentiation of human ESC, iPSC into otic cell types of the cochlea using threedimensional organoid culture system (13). Developing a new protocol for the hearing regeneration may provide better knowledge about the inner ear development. However, this method needs to be optimized in a wide range of pluripotent stem cells. Induced pluripotent stem cell (iPSC) is a type of pluripotent stem cell that are artificially made from somatic cells. These stem cells have the self-renewal capacity in vitro, they are able to form three primitive germ layers (ectoderm, mesoderm, and endoderm). Yamanaka and Takahashi first discovered iPSCs by cellular reprogramming method (14). Recently, Boddy et al. has developed nonintegrating mRNA reprogramming technology on iPSCs to produce otic cell lineages. This technology facilitates the limitation of genetic variability imposed by other cell reprogramming methods (viral reprogramming and DNAbased reprogramming) and are suggested as a novel tool in the field of regenerative medicine (15). However, tumor formation was observed after transplantation of iPSCs into the mouse cochlea, and this might be caused by the undifferentiated iPSCs (16).

Mesenchymal Stem Cells. Mesenchymal stem cells are adult stromal cells, characterized by non-hematopoietic, selfrenewing, multipotent, highly proliferative, adherent growing nature, paracrine activity and migration ability to the injury sites. The presence of MSCs in tissues is identified by the expression of surface antigens CD105, CD90 and CD73 (17). Bone marrow, umbilical cord, adipose tissue and placenta are rich sources of MSCs and used in variety of tissue regeneration studies (18). The risk of isolation of MSCs depends on different sources. For example, MSCs isolation from cord tissue and placenta is ethically unproblematic and non-invasive than other sources. Originally, MSCs were differentiated into bone cells, fat cells and cartilage cells. But recent studies have shown that MSCs can induce to differentiate auditory hair cells, neuronal cells and cochlear fibrocytes, which made a key milestone in hearing regeneration (19-21) (Tables I and II).

Mesenchymal Stem Cells in Inner Hair Cell Regeneration. In the cochlea, regeneration of auditory neurons and hair cells through the application of MSCs is not a simple process. It requires certain neurotrophic factors especially glial cell-derived neurotrophic factor, brain-derived neurotrophic factor and neurotrophin-3 (GDNF, BDNF, NT3 ) and growth factors for the differentiation of MSCs into auditory hair-like and neuronal cells (22-24). Evidence showed that mesenchymal stem cells could be able to differentiate auditory hair-like cells that were confirmed by the expression of hair cell markers Atoh1, Sox2, Jagged2, p27kip, Brn3c, Myosin VIIA and, Espin which are essential for inner ear development and hearing function (20). Administration of MSCs can cause diverse beneficial effects in in vivo models. In noise or drug-induced hearing loss model, the systemic administration of MSCs induces abundant neurotrophin expression in the cochlear injured 
in vivo $35: 13-22(2021)$

Table II. Studies of mesenchymal stem cells (MSCs) in animal models for hearing regeneration.

\begin{tabular}{|c|c|c|c|c|c|c|}
\hline $\begin{array}{l}\text { Author } \\
\text { (year) }\end{array}$ & $\begin{array}{l}\text { Type of mesenchymal } \\
\text { stem cells (MSCs) }\end{array}$ & $\begin{array}{l}\text { In vivo } \\
\text { model }\end{array}$ & $\begin{array}{l}\text { Delivery site of } \\
\text { transplantation }\end{array}$ & $\begin{array}{l}\text { Target } \\
\text { cells }\end{array}$ & $\begin{array}{l}\text { Hearing } \\
\text { outcome }\end{array}$ & Reference \\
\hline $\begin{array}{l}\text { Kamiya } \\
\text { et al. (2007) }\end{array}$ & Rat BM-MSCs & $\begin{array}{l}\text { Acute } \\
\text { sensorineural } \\
\text { hearing loss } \\
\text { rat model }\end{array}$ & $\begin{array}{l}\text { Lateral } \\
\text { semicircular } \\
\text { canal }\end{array}$ & $\begin{array}{l}\text { Cochlear } \\
\text { fibrocytes }\end{array}$ & $\begin{array}{l}\text { ABR: Hearing function } \\
\text { enhanced in MSCs treated } \\
\text { animals; the lateral wall of } \\
\text { transplanted MSCs expressed } \\
\text { gap junction proteins; this } \\
\text { might suggest that transplanted } \\
\text { MSCs induce the renewal } \\
\text { of cochlear fibrocytes }\end{array}$ & $(45)$ \\
\hline $\begin{array}{l}\text { Y. Zhou } \\
\text { et al. }(2011)\end{array}$ & Human ADSCs & $\begin{array}{l}\text { Experimental } \\
\text { autoimmune } \\
\text { hearing loss } \\
\text { mice }\end{array}$ & Intraperitoneal & $\begin{array}{l}\text { Immunoreactive } \\
\text { T-cells; } \\
\text { Cochlear hair } \\
\text { cells }\end{array}$ & $\begin{array}{l}\text { ABR: Hearing function } \\
\text { improved in hASCs-treated } \\
\text { groups; hASCs downregulated } \\
\text { Th1-mediated autoreactive } \\
\text { responses, which suppress } \\
\text { the self-reactive T-cells and } \\
\text { protecting cochlear hair } \\
\text { cells degeneration }\end{array}$ & (28) \\
\hline $\begin{array}{l}\text { Choi } \\
\text { et al. (2012) }\end{array}$ & $\begin{array}{l}\text { Human } \\
\text { BM-MSCs }\end{array}$ & $\begin{array}{l}\text { Noise or ototoxic- } \\
\text { induced hearing } \\
\text { loss rats }\end{array}$ & Systemic delivery & $\begin{array}{l}\text { Spiral } \\
\text { ganglions }\end{array}$ & $\begin{array}{l}\text { Delivery of MSCs to the } \\
\text { systemic site recruiting homing } \\
\text { factors to the damaged cochlea }\end{array}$ & (25) \\
\hline $\begin{array}{l}\text { M.Y. Choi } \\
\text { et al. (2012) }\end{array}$ & $\begin{array}{l}\text { Human } \\
\text { UCB-MSCs }\end{array}$ & $\begin{array}{c}\text { Sensorineural } \\
\text { hearing loss } \\
\text { (SNHL) guinea } \\
\text { pigs }\end{array}$ & Brachial vein & $\begin{array}{l}\text { Auditory hair } \\
\text { cells; Spiral } \\
\text { ganglion } \\
\text { neurons }\end{array}$ & $\begin{array}{l}\text { ABR and DPOAE: Hearing } \\
\text { thresholds increased in UCB-MSCs } \\
\text { treated SNHL groups; } \\
\text { Increased number of Spiral } \\
\text { ganglion neurons and } \\
\text { cochlear hair cells observed. }\end{array}$ & (30) \\
\hline $\begin{array}{l}\text { H. Kasagi } \\
\text { et al. }(2013)\end{array}$ & $\begin{array}{c}\text { Mice } \\
\text { BM-MSCs }\end{array}$ & C57BL/6J mice & $\begin{array}{l}\text { Posterior } \\
\text { semicircular } \\
\quad \text { canal }\end{array}$ & $\begin{array}{l}\text { Cochlear } \\
\text { fibrocytes }\end{array}$ & $\begin{array}{l}\text { Transplanted MSCs migrated } \\
\text { into the cochlea, where they } \\
\text { differentiated to fibrocyte- } \\
\text { like cells without any adverse } \\
\text { effects on hearing function }\end{array}$ & (46) \\
\hline $\begin{array}{l}\text { T. J. Yoo } \\
\text { et al. }(2015)\end{array}$ & $\begin{array}{l}\text { Human } \\
\text { ADSCs }\end{array}$ & $\begin{array}{l}\text { Experimental } \\
\text { autoimmune } \\
\text { hearing loss mice }\end{array}$ & Intraperitoneal & $\begin{array}{l}\text { Immunoreactive } \\
\text { T-cells; } \\
\text { Cochlear hair } \\
\text { cells }\end{array}$ & $\begin{array}{l}\text { ABR: Hearing function } \\
\text { improved in hASCs-treated } \\
\text { groups; hASCs suppressing } \\
\text { beta tubulin-reactive cells and } \\
\text { inducing the anti-inflammatory } \\
\text { cytokine, thereby exhibiting } \\
\text { therapeutic activity in the } \\
\text { hearing loss animals }\end{array}$ & (71) \\
\hline $\begin{array}{l}\text { K. Kil } \\
\text { et al. (2016) }\end{array}$ & $\begin{array}{l}\text { Human } \\
\text { PD-MSCs }\end{array}$ & $\begin{array}{c}\text { Sensorineural } \\
\text { hearing loss (SNHL) } \\
\text { guinea pigs }\end{array}$ & Brachial vein & $\begin{array}{l}\text { Spiral } \\
\text { ganglions }\end{array}$ & $\begin{array}{l}\text { ABR and DPOAE: } \\
\text { Hearing level improved in stem } \\
\text { cell treated animals; The } \\
\text { number of spiral ganglion } \\
\text { neurons increased in cochlea }\end{array}$ & (72) \\
\hline $\begin{array}{l}\text { Ma et al. } \\
\text { (2016) }\end{array}$ & $\begin{array}{l}\text { Human } \\
\text { UC-MSCs }\end{array}$ & $\begin{array}{l}\text { Congenital deaf } \\
\text { albino pigs }\end{array}$ & $\begin{array}{l}\text { Subarachnoid } \\
\text { cavity }\end{array}$ & $\begin{array}{l}\text { Cochlear } \\
\text { cells }\end{array}$ & $\begin{array}{l}\text { ABR: Delivery of UC-MSCs } \\
\text { into inner ear of deafness } \\
\text { pigs cause effective changes } \\
\text { in ABR response }\end{array}$ & (29) \\
\hline $\begin{array}{l}\text { S. Bettini } \\
\text { et al. (2018) }\end{array}$ & $\begin{array}{l}\text { Human } \\
\text { BM-MSCs; } \\
\text { ADSCs }\end{array}$ & $\begin{array}{l}\text { Kanamycin- } \\
\text { deafened } \\
\text { nod-scid mice }\end{array}$ & Intravenous & $\begin{array}{l}\text { Cochlear } \\
\text { cells }\end{array}$ & $\begin{array}{l}\text { Both the type of MSCs } \\
\text { induced the regeneration of } \\
\text { damaged sensory cochlear cells }\end{array}$ & (73) \\
\hline $\begin{array}{l}\text { Mittal } \\
\text { et al. (2019) }\end{array}$ & Rat BM-MSCs & $\begin{array}{l}\text { Sprague-Dawley } \\
\text { rats }\end{array}$ & $\begin{array}{c}\text { Intratympanic } \\
\text { delivery }\end{array}$ & $\begin{array}{l}\text { Cochlear } \\
\text { cells }\end{array}$ & $\begin{array}{l}\text { ABR and DPOAE: Treated } \\
\text { animals cochlear function } \\
\text { became normal as control } \\
\text { groups; No inflammatory } \\
\text { reactions observed. }\end{array}$ & $(21)$ \\
\hline
\end{tabular}

ABR, Auditory brainstem response; DPOAE, distortion product otoacoustic emissions; BM-MSCs, bone marrow mesenchymal stem cells; UC-MSCs, umbilical cord mesenchymal stem cells; PD-MSCs, placenta-derived mesenchymal stem cells; UCB-MSCs, umbilical cord blood mesenchymal stem cells; ADSCs, adipose-derived mesenchymal stem cells. 
sites, thereby promote the regeneration of auditory hair cells and neurons (25). In Sensorineural hearing loss patients, transplantation of autologous BM-MSCs showed no significant improvement in their hearing but no other complications and side-effects were found in their three year follow-up (26). However, when considering clinical trial aspects, therapeutic feasibility and safety measures must be assured. This study may give additional evidence for MSCs as the safest method in hearing loss. MSCs are considered as potent immunomodulators in various autoimmune inner ear diseases (27). In an autoimmune hearing loss murine model, human adipose-derived mesenchymal stem cells (h-ADSCs), h-ADSCs down-regulate Th1-mediated autoreactive response that recruits antigen-specific Treg cells to secrete interleukin10 and suppresses the self-reactive T-cells and protects cochlear hair cell loss from degeneration (28). Some studies showed that MSCs have a greater migration effect to the injured sites of the cochlea. The delivery of umbilical cordMSCs to the cerebrospinal fluid of congenital deaf albino pigs, facilitated enhanced migration of MSCs to different regions of inner ear cochlea, central nervous system and peripheral organs and also clinical adverse effects were not observed until eight weeks of transplantation (29). Another study by M.Y. Choi et al. reported that administration of UC blood-derived MSCs into the brachial vein of sensorineural hearing loss guinea pigs could enhance the number of missing or damaged neural cells in the spiral ganglion, replace damaged cochlear outer hair cells and significantly improve the auditory brainstem responses (ABRs) (30).

Mesenchymal Stem Cells in Spiral Ganglion Neurons (SGNs) Regeneration. In the central axis of the cochlea (modiolus), a group of neuron cell bodies are present, and are called spiral ganglion neurons (SGNs). They transmit the sound signals from the organ of Corti to auditory brainstem and stimulate the production of nerve impulses in the brain. In the auditory neuronal portion, two types (type I and type II) of ganglion cells are classified by their morphological structure, cell body, myelin sheath and biological function. Type I spiral ganglion cells are myelinated, large, bipolar cells and occupy $95 \%$ of the cochlear nerve cells and primarily innervate the inner ear hair cells, whereas the remaining nerve cells are composed of small, unmyelinated type II ganglion cells and innervate the outer hair cells (31). These ganglion cells perform different functions in auditory processing along with the sensory hair cells and the presence of a number of ganglion neuronal cells may vary among different species (32). Moreover, SGNs do not have the capacity of postembryonic cellular division, and cannot produce new sensory neurons when damage occurs (33). Generally, inner ear neuronal cells are regulated by predominant neurotrophic factors such as brain-derived neurotrophic factor (BDNF), neurotrophin-
3 (NT-3) and glial cell-derived neurotrophic factor (GDNF) (34). BDNF is one of the most abundant neurotrophins, present in the brain that facilitates neuronal growth and controls the production, absorption and elimination of neurotransmitters. NT-3 is another neurotrophin that provides support for the neuronal growth and differentiation (35). GDNF is involved in promoting cochlear neuronal cell survival. These neurotrophins are supplied either as a neuronal medium for the complete differentiation of BMMSCs to neuronal cells in vitro (36) or as genetically modified MSCs in the deafness animal model (37). A recent study established that genetically modified BDNFproducing MSCs in alginate-coated matrix protect the survival of SGNs from degeneration. In the drug delivery system, this encapsulation technique provides a good support for the survival of MSCs and their migratory control (38). Moreover, the higher proliferative potential of MSCs from Wharton's jelly was able to differentiate auditory neuronal cells in a culture medium containing neurotrophic factors GDNF, BDNF and NT-3 (39).

Mesenchymal Stem Cells in Spiral Ligament Fibrocytes (SLFS) Repair. In mammals, cochlear fibrocytes arise from non-sensory regions, contribute to normal hearing function and play a potential role in transporting potassium ions to generate endolymphatic potential in the scala media. These fibrocytes are majorly found in the lateral wall of the cochlear spiral ligament and stria vascularis. Fibrocytes expressing various proteins for homeostasis mechanism, ionic transportation, collagen metabolism, potassium recycling, and gap junction communication of inner ear cell types (40). Compared to other sensory cells, spiral ligament fibrocytes are able to renew themselves in the mammalian inner ear after drug exposure (41). Within the cochlear lateral wall, mature fibrocytes are classified into five types I-V based on the structural characteristics, location and immunostaining patterns $(40,42)$. Fibrocytes originated from mesodermal germ layer that form part of connective tissue. These cells are able to proliferate throughout the human lifespan. However, less proliferation was detected in the lateral wall of adult cochlea (43). SLFs degeneration or dysfunction may arise from excessive noise, aging or genetic mutations. Sun et al. investigated two mechanisms for the functional communication between MSCs and SLFs. The first is that transplanted MSCs in the inner ear could transdifferentiate into SLF-like cells which compensate for the missing SLFs. The other is that transplanted MSCs boost the proliferation and regeneration of damaged SLFs (44). In the sensory hearing loss model, the functional recovery of hearing achieved by transplantation of MSCs that could repair injured SLFs and damaged gap junction network through invasion, migration, and proliferation of MSCs in the lateral wall of the cochlea (45). In young mice cochlea, 
transplanted MSCs were able to migrate and differentiate into fibrocyte-like cells with no adverse effects on hearing function. In contrast, there were no migration or differentiation of MSCs observed after transplantation in adult mice. This study may suggest that MSCs transplantation could be a better treatment to delay or stop early progression of sensorineural hearing loss (46).

MSCs and Gene Therapy in Hearing Regeneration. Gene therapy is a modern treatment approach that is being used to deliver genes of interests for reversing or preventing disease conditions. Most gene therapeutic approaches rely on the viral vectors such as adeno-associated virus (AAV), adenovirus (AV), lentivirus (LV) and herpes virus (HV). These viral vectors are not pathogenic to the host cells, they do not have viral genes, they have high transduction efficiency and non-toxic to the host cells (47). One of the major challenges of gene therapy is achieving local delivery of viral vectors without any damage to sensitive inner ear structures (48). There are many genes, ATOH1, SOX2, OCT4, Myosin7A, GJB2 (connexin 26), Espin, and USHIC necessary for cochlear hair cells and supporting cell development. ATOH1 (also known as Mathl) gene encoding the basic helix-loop-helix transcription factor that is vital for inner ear hair cell differentiation (49). In a hearing loss animal model, adenoviral-mediated ATOH1 gene therapy effectively improved the regeneration of auditory hair cells (50). Another study evidenced that, adeno-associated virus (AAV)-mediated ATOH1 gene delivery could transfect supporting cells to induce the formation of new hair cells (51). In the last few years, MSCs are used as a therapeutic vehicle for gene therapy methods in various diseases. Different approaches (viral vector-based gene delivery, nonviral gene delivery) have been employed to introduce regenerative genes into MSCs. The advantage of MSCs in gene therapy is that they can be modified with a broad range of viral and non-viral vector systems. However, the transduction efficiency may differ with each vector (52). Genetically modified MSCs can be used to treat heart diseases, bone diseases, cancer, central nervous system diseases and autoimmune diseases (53). In hearing research, Devarajan et al. reported the delivery of the ATOH1 gene through adenovector mediated transduction into human umbilical cord mesenchymal stem cells induced to differentiate inner ear hair cells phenotype in vitro. These differentiated hair cells were confirmed by the expression of hair cell markers (54). This study provided a new foundation for hearing loss treatment. But there exists no further clinical evidence found for the combination of gene and stem cellbased therapies in hearing loss studies.

MSCs and siRNA in Hearing Regeneration. Small interfering RNAs (siRNAs) are short, non-coding double-stranded RNA molecules, specifically targeting disease-causing genes and silencing them. In an siRNA transfection study, different viral vectors, nucleic acid constructs, polyethylenimine vectors, recombinant proteins, nanoparticles, cationic liposomes have been used as delivery vehicles (55). In the inner ear, Notch signaling pathway is the main target for regeneration of hair cells. Modulation of notch downstream molecule Hes 1 with siRNA is enough for the ATOHI gene up-regulation and promotes an increase in hair cell number. Significant recovery of hearing function attained by delivery of siHes 1 encapsulated nanoparticles in a hearing loss animal model (56). To enhance the therapeutic applicability of siRNA in ototoxicity, siMAPK1 nanoparticle treatment was used to reduce the systemic administration of cisplatin-ototoxic effects in hair cell lines (57). However, delivery efficiency, inflammatory reaction and, target gene selection limit the success of siRNA molecules (47). For the first time, Mellott et al. assessed the functional role of ATOH1 gene homologues (HATH1 and MATH1) in human Wharton's jellyderived stem cells by the non-viral reprogramming approach. The study hypothesized that, both the ATOHI gene homologues were not functionally similar in human tissues and the knockdown of Hesl and Hes5 (negative regulators of inner ear hair cell differentiation) in conjunction with ATOH1 homologues overexpression increases the atonal function could induce the hair cell development (58). However, further clinical evidence is required to show the therapeutic effect of MSCs with siRNA in hearing regeneration.

MSCs and miRNA in Hearing Regeneration. MicroRNAs (miRNAs) are small, non-coding RNA molecules, highly conserved in many species, that regulate physiological, biological and pathological processes in inner ear development (59). Apart from other essential genes, these small molecules also participate in hearing regeneration. In SNHL, some of these miRNAs are identified as biomarkers for diagnosing age-related and noise-induced hearing loss. Several miRNAs play a major role in the inner ear, and their targets play a role in hearing regulation (60). Wang et al. performed a study on mouse otocyst-derived cells, where mir-182 promoted the differentiation of otocyst cell fate into hair-like cells and as the transcription factor $T b x l$ was functionally influenced by miR-182, and was found to be the target of miRNA-182, thereby providing a crucial gene in development of the inner ear (61). MiR-183 family has three homologues (miR-183, miR-182 and miR-96) that are abundantly expressed in vertebrates of auditory hair cells and sensory neurons (62). Activation of this microRNA family homologues is essential for the development of inner ear stereociliary hair bundle formation and cochlear hair cell function (63). Transdifferentiation is a cellular process of conversion of one cell type into another type without self-renewal of the original cell. In the organ of Corti, miRNA-210 promote the 
transdifferentiation of epithelial cells to sensory hair cells (64). Apart from that, a transfection agent was used to study the expression of hair cell-specific markers in mesenchymal stem cells. This study established that, transfection of microRNA (mir-182, mir-183 and mir-96) mimics into human BM-MSCs facilitated hair cell markers up-regulation. Among three microRNAs, miR-182 could enhance the differentiation of MSCs, therefore microRNA function could serve a precise role in hair cell differentiation (65).

Clinical Challenges of MSCs Administration in the Cochlea. Stem cell administration to the inner ear cochlea is not a simple procedure. It is associated with various risks and challenges. Some of the clinical issues, the proper efficient distribution, migration, immunocompatibility and retaining the cells alive at the target sites must be resolved when using MSC therapy. Inside the cochlea, a specific microenvironment is required to facilitate the survival of exogenously transplanted stem cells (66). Stem cells can be delivered through tympanic or vestibular duct, which contain perilymph fluid, but need to cross the membrane barriers (Reissner's or basilar membranes) to reach the organ of Corti. This will be the biggest challenge for transplanted MSCs. To overcome this, stem cells might be directly delivered to the cochlear duct that could make some beneficial effect. However, the higher concentration of potassium ions in the endolymph can lead to endolymphatic fluid toxicity that will disrupt the function of neighboring hair cells and supporting cells and decrease the viability of transplanted cells. Furosemide injection may be helpful to reduce the endocochlear potential toxicity in scala media (67). Furthermore, transplantation of MSCs into different sites of the cochlea may show better results and also cause damage to the inner ear structure, infection or other complications, further weakening of hearing by affecting organ of Corti cells. Intravenous or local administration requires more volume of MSCs and rarely crosses the blood brain barrier, therefore causing a reduction in the cell migration to the target sites (26). For example, Choi et al. demonstrated that intravenously injected MSCs to noise or drug-induced hearing loss rats were greatly trapped in the lungs than other injured sites (25). Overall, various physiological and cytotoxic barriers in the mammalian inner ear cochlea may have a significant impact on the transplanted stem cell distribution, migration and survival.

\section{Conclusion}

Different approaches (stem cell therapy, gene therapy, small interference RNA and microRNA) are being developed for the treatment of hearing loss. Among them, mesenchymal stem cell therapy provides a new hope for otolaryngologists. The reason is mesenchymal stem cells own significant properties such as self-renewal, multipotency, higher proliferation potential, migration, and paracrine activity. The MSCs isolation procedure may vary by sources (bone marrow, adipose tissue, umbilical cord and placenta), but the functional features are almost similar. For example, the isolation of MSCs from bone marrow is an invasive and painful procedure compared to using the umbilical cord. But both MSCs can exhibit similar morphology, surface marker expression, colony formation, doubling time, migration, differentiation potential and immunomodulation. Though many experimental studies show possible outcome of MSCbased therapy in regenerative medicine, some of the challenges are encountered by it. The main challenge is to achieve successful delivery of MSCs to the target sites. Sometimes, transplanted MSCs may cause incompatibility, inflammation and tumor formation to the experimental animals. Besides, a suitable microenvironment is necessary for the MSCs survival and migration. Still, many in vitro studies provide deep insight for the therapeutic application of MSCs. Continuous research in this area is required to establish the complete mesenchymal stem cell approach in pre-clinical and clinical evaluation.

\section{Conflicts of Interest}

The Authors declare no conflicts of interest with regard to the present study.

\section{Authors' Contributions}

Maharajan $\mathrm{N}$ and Cho GW wrote the article, Jang $\mathrm{CH}$ designed and supervised the study.

\section{Acknowledgements}

This work was supported by grants from the Basic Science Research Program through the National Research Foundation of Korea (NRF) funded by the Ministry of Education, Science and Technology (NRF- 2018-R1D-1A1B07048074) and National Research Foundation of Korea (NRF) funded by the Ministry of Science and ICT for Bioinspired Innovation Technology Development Project (NRF-2018M3C1B7021997).

\section{References}

1 Nacher-Soler G, Garrido JM and Rodríguez-Serrano F: Hearing regeneration and regenerative medicine: Present and future approaches. Arch Med Sci 15(4): 957-967, 2019. PMID: 31360190. DOI: 10.5114/aoms.2019.86062

2 Ouda L, Profant $\mathrm{O}$ and Syka J: Age-related changes in the central auditory system. Cell Tissue Res 361(1): 337-358, 2015. PMID: 25630878. DOI: 10.1007/s00441-014-2107-2

3 Dufner-Almeida LG, Cruz DBD, Mingroni Netto RC, Batissoco AC, Oiticica J and Salazar-Silva R: Stem-cell therapy for hearing loss: Are we there yet? Braz J Otorhinolaryngol 85(4): 520-529, 2019. PMID: 31186186. DOI: 10.1016/j.bjorl. 2019.04.006 
4 Groves AK: The challenge of hair cell regeneration. Exp Biol Med (Maywood) 235(4): 434-446, 2010. PMID: 20407075. DOI: $10.1258 / \mathrm{ebm} .2009 .009281$

5 Wangemann P: Supporting sensory transduction: Cochlear fluid homeostasis and the endocochlear potential. J Physiol 576(Pt 1): 11-21, 2006. PMID: 16857713. DOI: 10.1113/jphysiol.2006.112888

6 Raphael Y and Altschuler RA: Structure and innervation of the cochlea. Brain Res Bull 60(5-6): 397-422, 2003. PMID: 12787864. DOI: 10.1016/s0361-9230(03)00047-9

7 Monzack EL and Cunningham LL: Lead roles for supporting actors: Critical functions of inner ear supporting cells. Hear Res 303: 2029, 2013. PMID: 23347917. DOI: 10.1016/j.heares.2013.01.008

8 Devarajan K, Staecker H and Detamore MS: A review of gene delivery and stem cell based therapies for regenerating inner ear hair cells. J Funct Biomater 2(3): 249-270, 2011. PMID: 24956306. DOI: $10.3390 /$ jfb 2030249

9 Ding J, Tang Z, Chen J, Shi H, Chen J, Wang C, Zhang C, Li L, Chen $\mathrm{P}$ and Wang J: Induction of differentiation of human embryonic stem cells into functional hair-cell-like cells in the absence of stromal cells. Int J Biochem Cell Biol 81(Pt A): 208222, 2016. PMID: 26615761. DOI: 10.1016/j.biocel.2015.11.012

10 Lee MY, Hackelberg S, Green KL, Lunghamer KG, Kurioka T, Loomis BR, Swiderski DL, Duncan RK and Raphael Y: Survival of human embryonic stem cells implanted in the guinea pig auditory epithelium. Sci Rep 7: 46058, 2017. PMID: 28387239. DOI: $10.1038 /$ srep46058

11 Zhao LD, Li L, Wu N, Li DK, Ren LL, Guo WW, Sun JH, Liu HZ, Chen ZT, Xing GQ and Yang SM: Migration and differentiation of mouse embryonic stem cells transplanted into mature cochlea of rats with aminoglycoside-induced hearing loss. Acta Otolaryngol 133(2): 136-143, 2013. PMID: 23050670. DOI: $10.3109 / 00016489.2012 .720029$

12 Green RM: Can we develop ethically universal embryonic stemcell lines? Nat Rev Genet 8(6): 480-485, 2007. PMID: 17510667. DOI: $10.1038 / \mathrm{nrg} 2066$

13 Jeong M, O'Reilly M, Kirkwood NK, Al-Aama J, Lako M, Kros $\mathrm{CJ}$ and Armstrong L: Generating inner ear organoids containing putative cochlear hair cells from human pluripotent stem cells. Cell Death Dis 9(9): 922, 2018. PMID: 30206231. DOI: 10.1038/s41419-018-0967-1

14 Takahashi K and Yamanaka S: Induction of pluripotent stem cells from mouse embryonic and adult fibroblast cultures by defined factors. Cell 126(4): 663-676, 2006. PMID: 16904174. DOI: 10.1016/j.cell.2006.07.024

15 Boddy SL, Romero-Guevara R, Ji AR, Unger C, Corns L, Marcotti W and Rivolta MN: Generation of otic lineages from integration-free human-induced pluripotent stem cells reprogrammed by mrnas. Stem Cells Int 2020: 3692937, 2020. PMID: 32190057. DOI: 10.1155/2020/3692937

16 Zhu H, Chen J, Guan L, Xiong $\mathrm{S}$ and Jiang H: The transplantation of induced pluripotent stem cells into the cochleae of mature mice. Int J Clin Exp Pathol 11(9): 44234430, 2018. PMID: 31949839

17 Guadix JA, Zugaza JL and Gálvez-Martín P: Characteristics, applications and prospects of mesenchymal stem cells in cell therapy. Med Clin (Barc) 148(9): 408-414, 2017. PMID: 28126234. DOI: 10.1016/j.medcli.2016.11.033

18 Ding DC, Shyu WC and Lin SZ: Mesenchymal stem cells. Cell Transplant 20(1): 5-14, 2011. PMID: 21396235. DOI: $10.3727 / 096368910 x$
19 Jang S, Cho HH, Kim SH, Lee KH, Jun JY, Park JS, Jeong HS and Cho YB: Neural-induced human mesenchymal stem cells promote cochlear cell regeneration in deaf guinea pigs. Clin Exp Otorhinolaryngol 8(2): 83-91, 2015. PMID: 26045904. DOI: $10.3342 /$ ceo.2015.8.2.83

20 Jeon SJ, Oshima K, Heller S and Edge AS: Bone marrow mesenchymal stem cells are progenitors in vitro for inner ear hair cells. Mol Cell Neurosci 34(1): 59-68, 2007. PMID: 17113786. DOI: $10.1016 / j . m c n .2006 .10 .003$

21 Mittal R, Ocak E, Zhu A, Perdomo MM, Pena SA, Mittal J, Bohorquez $\mathrm{J}$ and Eshraghi AA: Effect of bone marrow-derived mesenchymal stem cells on cochlear function in an experimental rat model. Anat Rec (Hoboken) 303(3): 487-493, 2020. PMID: 30632683. DOI: 10.1002/ar.24065

22 Gonmanee T, Thonabulsombat C, Vongsavan K and Sritanaudomchai H: Differentiation of stem cells from human deciduous and permanent teeth into spiral ganglion neuron-like cells. Arch Oral Biol 88: 34-41, 2018. PMID: 29407749. DOI: 10.1016/j.archoralbio.2018.01.011

23 Mahmoudian-Sani MR, Hashemzadeh-Chaleshtori M, Jami MS and Saidijam M: In vitro differentiation of human bone marrow mesenchymal stem cells to hair cells using growth factors. Int Tinnitus J 21(2): 179-184, 2017. PMID: 29336137. DOI: 10.5935/0946-5448.20170030

24 Young E, Westerberg B, Yanai A and Gregory-Evans K: The olfactory mucosa: A potential source of stem cells for hearing regeneration. Regen Med 13(5): 581-593, 2018. PMID: 30113240. DOI: $10.2217 / \mathrm{rme}-2018-0009$

25 Choi BY, Song JJ, Chang SO, Kim SU and Oh SH: Intravenous administration of human mesenchymal stem cells after noise- or druginduced hearing loss in rats. Acta Otolaryngol 132 Suppl 1: S94-102, 2012. PMID: 22582790. DOI: 10.3109/00016489.2012.660731

26 Lee HS, Kim WJ, Gong JS and Park KH: Clinical safety and efficacy of autologous bone marrow-derived mesenchymal stem cell transplantation in sensorineural hearing loss patients. J Audiol Otol 22(2): 105-109, 2018. PMID: 29301392. DOI: 10.7874/jao.2017.00150

27 Shamriz O, Tal Y and Gross M: Autoimmune inner ear disease: Immune biomarkers, audiovestibular aspects, and therapeutic modalities of cogan's syndrome. J Immunol Res 2018: 1498640, 2018. PMID: 29850616. DOI: 10.1155/2018/1498640

28 Zhou Y, Yuan J, Zhou B, Lee AJ, Lee AJ, Ghawji M, Jr. and Yoo TJ: The therapeutic efficacy of human adipose tissue-derived mesenchymal stem cells on experimental autoimmune hearing loss in mice. Immunology 133(1): 133-140, 2011. PMID: 21366561. DOI: 10.1111/j.1365-2567.2011.03421.x

29 Ma Y, Guo W, Yi H, Ren L, Zhao L, Zhang Y, Yuan S, Liu R, $\mathrm{Xu}$ L, Cong T, Ek O, Zhai S and Yang S: Transplantation of human umbilical cord mesenchymal stem cells in cochlea to repair sensorineural hearing. Am J Transl Res 8(12): 5235-5245, 2016. PMID: 28077998.

30 Choi MY, Yeo SW and Park KH: Hearing restoration in a deaf animal model with intravenous transplantation of mesenchymal stem cells derived from human umbilical cord blood. Biochem Biophys Res Commun 427(3): 629-636, 2012. PMID: 23026045. DOI: $10.1016 / j . b b r c .2012 .09 .111$

31 Carricondo F and Romero-Gómez B: The cochlear spiral ganglion neurons: The auditory portion of the viii nerve. Anat Rec (Hoboken) 302(3): 463-471, 2019. PMID: 29659185. DOI: $10.1002 /$ ar. 23815 
32 Nayagam BA, Muniak MA and Ryugo DK: The spiral ganglion: Connecting the peripheral and central auditory systems. Hear Res 278(1-2): 2-20, 2011. PMID: 21530629. DOI: 10.1016/ j.heares.2011.04.003

33 Duan M, Agerman K, Ernfors P and Canlon B: Complementary roles of neurotrophin 3 and a n-methyl-d-aspartate antagonist in the protection of noise and aminoglycoside-induced ototoxicity. Proc Natl Acad Sci USA 97(13): 7597-7602, 2000. PMID: 10861021. DOI: 10.1073/pnas.97.13.7597

34 Pirvola U, Ylikoski J, Palgi J, Lehtonen E, Arumäe U and Saarma M: Brain-derived neurotrophic factor and neurotrophin 3 mrnas in the peripheral target fields of developing inner ear ganglia. Proc Natl Acad Sci USA 89(20): 9915-9919, 1992. PMID: 1409719. DOI: 10.1073/pnas.89.20.9915

35 Pirvola U and Ylikoski J: Neurotrophic factors during inner ear development. Curr Top Dev Biol 57: 207-223, 2003. PMID: 14674482. DOI: 10.1016/s0070-2153(03)57007-7

36 Lee JH, Kang WK, Seo JH, Choi MY, Lee YH, Kim HM and Park KH: Neural differentiation of bone marrow-derived mesenchymal stem cells: Applicability for inner ear therapy. Korean J Audiol 16(2): 47-53, 2012. PMID: 24653871. DOI: $10.7874 / \mathrm{kja} .2012 .16 .2 .47$

37 Scheper V, Hoffmann A, Gepp MM, Schulz A, Hamm A, Pannier C, Hubka P, Lenarz T and Schwieger J: Stem cell based drug delivery for protection of auditory neurons in a guinea pig model of cochlear implantation. Front Cell Neurosci 13: 177, 2019. PMID: 31139049. DOI: 10.3389/fncel.2019. 00177

38 Schwieger J, Hamm A, Gepp MM, Schulz A, Hoffmann A, Lenarz $\mathrm{T}$ and Scheper V: Alginate-encapsulated brain-derived neurotrophic factor-overexpressing mesenchymal stem cells are a promising drug delivery system for protection of auditory neurons. J Tissue Eng 11: 2041731420911313, 2020. PMID: 32341778. DOI: $10.1177 / 2041731420911313$

39 Kil K, Choi MY and Park KH: In vitro differentiation of human wharton's jelly-derived mesenchymal stem cells into auditory hair cells and neurons. J Int Adv Otol 12(1): 37-42, 2016. PMID: 27340981. DOI: 10.5152 /iao.2016.1190

40 Furness DN: Forgotten fibrocytes: A neglected, supporting cell type of the cochlea with the potential to be an alternative therapeutic target in hearing loss. Front Cell Neurosci 13: 532, 2019. PMID: 31866825 . DOI: 10.3389 /fncel.2019.00532

41 Lang H, Schulte BA and Schmiedt RA: Effects of chronic furosemide treatment and age on cell division in the adult gerbil inner ear. J Assoc Res Otolaryngol 4(2): 164-175, 2003. PMID: 12943371. DOI: $10.1007 / \mathrm{s} 10162-002-2056-4$

42 Spicer SS and Schulte BA: The fine structure of spiral ligament cells relates to ion return to the stria and varies with placefrequency. Hear Res 100(1-2): 80-100, 1996. PMID: 8922982. DOI: 10.1016/0378-5955(96)00106-2

43 Li Y, Watanabe K, Fujioka M and Ogawa K: Characterization of slow-cycling cells in the mouse cochlear lateral wall. PLoS One 12(6): e0179293, 2017. PMID: 28632772. DOI: 10.1371/ journal.pone.0179293

44 Sun GW, Fujii $M$ and Matsunaga T: Functional interaction between mesenchymal stem cells and spiral ligament fibrocytes. J Neurosci Res 90(9): 1713-1722, 2012. PMID: 22535531. DOI: 10.1002/jnr.23067

45 Kamiya K, Fujinami Y, Hoya N, Okamoto Y, Kouike H, Komatsuzaki R, Kusano R, Nakagawa S, Satoh H, Fujii M and
Matsunaga T: Mesenchymal stem cell transplantation accelerates hearing recovery through the repair of injured cochlear fibrocytes. Am J Pathol 171(1): 214-226, 2007. PMID: 17591967. DOI: 10.2353/ajpath.2007.060948

46 Kasagi H, Kuhara T, Okada H, Sueyoshi N and Kurihara H: Mesenchymal stem cell transplantation to the mouse cochlea as a treatment for childhood sensorineural hearing loss. Int J Pediatr Otorhinolaryngol 77(6): 936-942, 2013. PMID: 23561635. DOI: 10.1016/j.ijporl.2013.03.011

47 Hildebrand MS, Newton SS, Gubbels SP, Sheffield AM, Kochhar A, de Silva MG, Dahl HM, Rose SD, Behlke MA and Smith RJ: Advances in molecular and cellular therapies for hearing loss. Mol Ther 16(2): 224-236, 2008. PMID: 18223547. DOI: $10.1038 /$ sj.mt.6300351

48 Ren Y, Landegger LD and Stankovic KM: Gene therapy for human sensorineural hearing loss. Front Cell Neurosci 13: 323, 2019. PMID: 31379508. DOI: 10.3389/fncel.2019.00323

49 Bermingham NA, Hassan BA, Price SD, Vollrath MA, Ben-Arie N, Eatock RA, Bellen HJ, Lysakowski A and Zoghbi HY: Math1: An essential gene for the generation of inner ear hair cells. Science 284(5421): 1837-1841, 1999. PMID: 10364557. DOI: $10.1126 /$ science.284.5421.1837

50 Izumikawa M, Minoda R, Kawamoto K, Abrashkin KA, Swiderski DL, Dolan DF, Brough DE and Raphael Y: Auditory hair cell replacement and hearing improvement by atoh1 gene therapy in deaf mammals. Nat Med 11(3): 271-276, 2005. PMID: 15711559. DOI: 10.1038/nm1193

51 Tan F, Chu C, Qi J, Li W, You D, Li K, Chen X, Zhao W, Cheng C, Liu X, Qiao Y, Su B, He S, Zhong C, Li H, Chai R and Zhong G: Aav-ie enables safe and efficient gene transfer to inner ear cells. Nat Commun 10(1): 3733, 2019. PMID: 31427575. DOI: $10.1038 / \mathrm{s} 41467-019-11687-8$

52 Mohammadian M, Abasi E and Akbarzadeh A: Mesenchymal stem cell-based gene therapy: A promising therapeutic strategy. Artif Cells Nanomed Biotechnol 44(5): 1206-1211, 2016. PMID: 26148175. DOI: $10.3109 / 21691401.2015 .1029624$

53 Wei W, Huang Y, Li D, Gou HF and Wang W: Improved therapeutic potential of mscs by genetic modification. Gene Ther 25(8): 538-547, 2018. PMID: 30254305. DOI: 10.1038/s41434018-0041-8

54 Devarajan K, Forrest ML, Detamore MS and Staecker H: Adenovector-mediated gene delivery to human umbilical cord mesenchymal stromal cells induces inner ear cell phenotype. Cell Reprogram 15(1): 43-54, 2013. PMID: 23379581. DOI: 10.1089/cell.2011.0097

55 Maeda Y, Sheffield AM and Smith RJH: Therapeutic regulation of gene expression in the inner ear using rna interference. Adv Otorhinolaryngol 66: 13-36, 2009. PMID: 19494570. DOI: 10.1159/000218205

56 Du X, Cai Q, West MB, Youm I, Huang X, Li W, Cheng W, Nakmali D, Ewert DL and Kopke RD: Regeneration of cochlear hair cells and hearing recovery through hes 1 modulation with sirna nanoparticles in adult guinea pigs. Mol Ther 26(5): 13131326, 2018. PMID: 29680697. DOI: 10.1016/j.ymthe.2018. 03.004

57 Youm I, West MB, Li W, Du X, Ewert DL and Kopke RD: Sirna-loaded biodegradable nanocarriers for therapeutic mapk1 silencing against cisplatin-induced ototoxicity. Int $\mathrm{J}$ Pharm 528(1-2): 611-623, 2017. PMID: 28627458. DOI: 10.1016/ j.ijpharm.2017.06.035 
58 Mellott AJ, Devarajan K, Shinogle HE, Moore DS, Talata Z, Laurence JS, Forrest ML, Noji S, Tanaka E, Staecker H and Detamore MS: Nonviral reprogramming of human wharton's jelly cells reveals differences between atoh 1 homologues. Tissue Eng Part A 21(11-12): 1795-1809, 2015. PMID: 25760435. DOI: 10.1089/ten.TEA.2014.0340

59 Wang XR, Zhang XM, Zhen J, Zhang PX, Xu G and Jiang H: Microrna expression in the embryonic mouse inner ear. Neuroreport 21(9): 611-617, 2010. PMID: 20467336. DOI: 10.1097/WNR.0b013e328338864b

60 Mahmoudian-Sani MR, Mehri-Ghahfarrokhi A, Ahmadinejad F, Hashemzadeh-Chaleshtori M, Saidijam M and Jami MS: Micrornas: Effective elements in ear-related diseases and hearing loss. Eur Arch Otorhinolaryngol 274(6): 2373-2380, 2017. PMID: 28224282. DOI: 10.1007/s00405-017-4470-6

61 Wang XR, Zhang XM, Du J and Jiang H: Microrna-182 regulates otocyst-derived cell differentiation and targets t-box1 gene. Hear Res 286(1-2): 55-63, 2012. PMID: 22381690. DOI: 10.1016/j.heares.2012.02.005

62 Mahmoodian Sani MR, Hashemzadeh-Chaleshtori M, Saidijam M, Jami MS and Ghasemi-Dehkordi P: Microrna-183 family in inner ear: Hair cell development and deafness. J Audiol Otol 20(3): 131-138, 2016. PMID: 27942598. DOI: 10.7874/jao. 2016.20.3.131

63 Geng R, Furness DN, Muraleedharan CK, Zhang J, Dabdoub A, Lin V and Xu S: The microrna-183/96/182 cluster is essential for stereociliary bundle formation and function of cochlear sensory hair cells. Sci Rep 8(1): 18022, 2018. PMID: 30575790. DOI: $10.1038 / \mathrm{s} 41598-018-36894-\mathrm{Z}$

64 Riccardi S, Bergling S, Sigoillot F, Beibel M, Werner A, Leighton-Davies J, Knehr J, Bouwmeester T, Parker CN, Roma $\mathrm{G}$ and Kinzel B: Mir-210 promotes sensory hair cell formation in the organ of corti. BMC Genomics 17: 309, 2016. PMID: 27121005. DOI: 10.1186/s12864-016-2620-7

65 Mahmoudian-Sani MR, Jami MS, Mahdavinezhad A, Amini R, Farnoosh G and Saidijam M: The effect of the microrna-183 family on hair cell-specific markers of human bone marrowderived mesenchymal stem cells. Audiol Neurootol 23(4): 208215, 2018. PMID: 30380528. DOI: 10.1159/000493557

66 Schulze J, Sasse S, Prenzler N, Staecker H, Mellott AJ, Roemer A, Durisin M, Lenarz T and Warnecke A: Microenvironmental support for cell delivery to the inner ear. Hear Res 368: 109-122, 2018. PMID: 29945803. DOI: 10.1016/j.heares.2018.06.015
67 Park YH, Wilson KF, Ueda Y, Tung Wong H, Beyer LA, Swiderski DL, Dolan DF and Raphael Y: Conditioning the cochlea to facilitate survival and integration of exogenous cells into the auditory epithelium. Mol Ther 22(4): 873-880, 2014. PMID: 24394296. DOI: 10.1038/mt.2013.292

68 Qin H, Zhao LD, Sun JH, Ren LL, Guo WW, Liu HZ, Zhai SQ and Yang SM: The differentiation of mesenchymal stem cells into inner ear hair cell-like cells in vitro. Acta Otolaryngol 131(11): 1136-1141, 2011. PMID: 21838606. DOI: 10.3109/ 00016489.2011 .603135

69 Durán Alonso MB, Feijoo-Redondo A, Conde de Felipe M, Carnicero E, García AS, García-Sancho J, Rivolta MN, Giráldez $\mathrm{F}$ and Schimmang T: Generation of inner ear sensory cells from bone marrow-derived human mesenchymal stem cells. Regen Med 7(6): 769-783, 2012. PMID: 23164078. DOI: 10.2217/rme. 12.65

70 Boddy SL, Chen W, Romero-Guevara R, Kottam L, Bellantuono I and Rivolta MN: Inner ear progenitor cells can be generated in vitro from human bone marrow mesenchymal stem cells. Regen Med 7(6): 757-767, 2012. PMID: 23164077. DOI: 10.2217/ rme.12.58

71 Yoo TJ, Du X and Zhou B: The paracrine effect of mesenchymal human stem cells restored hearing in $\beta$-tubulin induced autoimmune sensorineural hearing loss. Hear Res 330(Pt A): 5761, 2015. PMID: 26235980. DOI: 10.1016/j.heares.2015.07.021

72 Kil K, Choi MY, Kong JS, Kim WJ and Park KH: Regenerative efficacy of mesenchymal stromal cells from human placenta in sensorineural hearing loss. Int J Pediatr Otorhinolaryngol 91: 7281, 2016. PMID: 27863646. DOI: 10.1016/j.ijporl.2016.10.010

73 Bettini S, Franceschini V, Astolfi L, Simoni E, Mazzanti B, Martini A and Revoltella RP: Human mesenchymal stromal cell therapy for damaged cochlea repair in nod-scid mice deafened with kanamycin. Cytotherapy 20(2): 189-203, 2018. PMID: 29246648. DOI: 10.1016/j.jcyt.2017.11.003

Received September 13, 2020

Revised September 27, 2020

Accepted September 30, 2020 